\title{
Análise dos comportamentos ambiental e político em assentamentos rurais do Distrito Federal e entorno
}

\author{
Luciano Pereira da Silva* \\ Manoel Pereira de Andrade*** \\ Luiz Honorato da Silva Junior ${ }^{* * * *}$
}

\begin{abstract}
Resumo
O objetivo deste artigo é descrever o perfil socioeconômico e realizar uma análise dos comportamentos ambiental e político dos assentados presentes nos assentamentos rurais do Distrito Federal e entorno. A elaboração do perfil socioeconômico bem como a mensuração dos comportamentos político e ambiental dos assentados foram inferidas por meio do cálculo do Indice de Sustentabilidade Ambiental e do Índice de Participação Política. Foram aplicados 408 questionários em 11 assentamentos da Região Integrada de Desenvolvimento do Distrito Federal e Entorno. Constatou-se a presença de traços de dicotomia imposta ao meio rural, como o homem do campo ainda é visto como ator marginal na transformação de seu próprio meio. O nível de escolaridade é baixo, ainda causado por desníveis na oferta de políticas educacionais voltadas para a realidade rural. Os assentados apresentam níveis intermediários em ambos os comportamentos, mensurados por meio dos índices, sendo que alguns indicadores analisados precisam ser melhorados, bem como outros precisam ser potencializados.
\end{abstract}

Palavras-chave: Assentamentos. Participação política. Sustentabilidade ambiental.

* Professor do Instituto Federal de Brasília. E-mail: lucianosrp@gmail.com

** Professor adjunto da Universidade de Brasília. E-mail: manoelpandrade@gmail.com

***** Professor adjunto da Universidade de Brasília. E-mail: lula_honorato@gmail.com

http://dx.doi.org/10.5335/rtee.v22i46.6754

Submissão : 13/01/2015. Aceite: 22/11/2015. 


\section{Introdução}

As novas propostas de desenvolvimento em discussão se dão em torno da sustentabilidade, uma vez que os desafios e as discussões sobre esse tema tornaram-se amplos e globais. As palavras que definem melhor esse momento de complexidade seriam crise e mudança. A crise que envolve os paradigmas do século XXI é de ordem econômica, social e ambiental, necessitando de uma reconfiguração dos atores sociais e agentes econômicos, ou seja, existe uma profunda alteração nas relações de produção, afetando o mundo do trabalho, sustentado principalmente pelo desenvolvimento tecnológico, bem como várias lacunas no sentido de garantir a conservação de recursos, gerar fontes alternativas de produção, promover melhorias sociais e permitir o acesso de todos aos bens essenciais à vida humana.

Nesse sentido, as configurações econômicas mundiais para o século XXI requerem a construção de políticas de desenvolvimento calcadas na construção de práticas das ações públicas, que possam promover o desenvolvimento com mais equidade social e eficiência econômica. As ações predatórias do sistema capitalista de produção provocam desequilíbrios acentuados no meio rural brasileiro. No "novo" rural brasileiro, predominam relações de produção sob domínio das ações capitalistas.

A utilização do termo "novo" relaciona-se também às novas atividades desenvolvidas no campo, essas atividades não são tão novas assim, pois, na verdade, elas deixam de ser hobbies para serem atividades com grande valorização e que estão desenvolvendo a urbanização do meio rural (DEL GROSSI; SILVA, 2002).

Leff (2008) defende que o conceito de desenvolvimento sustentável, além de incluir a dimensão ambiental, também implica na necessidade de gerar condições econômicas e políticas que permitam a participação comunitária na definição de suas necessidades, na autogestão de seus recursos, na produção de seus fatores bem como na inovação, assimilação e adaptação de tecnologias voltadas para a sustentabilidade. Sendo assim, o desenvolvimento sustentável, a partir de um conceito de ambiente, também poderá promover equidade social, com autonomia cultural e independência política dos povos.

Essa participação deve ter um caráter político. Segundo Gohn (2001), ela deve ser plural, não se tratando de indivíduos isolados e nem de indivíduos membros de um grupo social, mas que devem dividir responsabilidades com a comunidade, e não apenas colocá-la como um ator marginal em programas esporádicos: 
A participação envolve também lutas pela divisão das responsabilidades dentro do governo. Essas lutas possuem várias frentes, tais como a constituição de uma linguagem democrática não excludente nos espaços participativos criados ou existentes, o acesso dos cidadãos a todo tipo de informação que lhe diga respeito e o estímulo à criação e desenvolvimento de meios democráticos de comunicações (2001, p. 19).

No meio rural brasileiro, a participação teve impulso, principalmente, por meio de movimentos baseados em correntes ideológicas específicas. Todavia, o foco era a luta pela terra, que transcorreu toda a história do Brasil, e ainda hoje ocupa posição central nas plataformas de discussões que colocam a moradia e o acesso a esse fator de produção como primordiais para um desenvolvimento com equidade social.

Sauer e Souza (2008) destacam que a organização e mobilização dos movimentos sociais agrários têm uma unificação na luta por direitos, especialmente pelo direito à terra e, por extensão, ao trabalho, à moradia, à saúde, à educação, enfim, a uma vida digna no campo.

Uma das formas de se garantir a terra e, consequentemente, a moradia foi a instalação de assentamentos rurais. $\mathrm{O}$ assentamento rural é uma das formas objetivas de se fazer uma reforma agrária. Bergamasco e Norder acreditam que:

[...] de maneira genérica, os assentamentos rurais podem ser definidos como a criação de novas unidades de produção agrícola, por meio de políticas governamentais visando o reordenamento do uso da terra, em benefício de trabalhadores rurais sem terra ou com pouca terra (1996, p. 7).

Os assentamentos rurais brasileiros são frutos de intensas lutas de movimentos sociais pela reforma agrária promovidas pelos trabalhadores rurais. Desempenham um importante papel no espaço rural brasileiro devido à contribuição social e econômica que podem surgir com a geração de emprego, a diminuição do êxodo rural, o aumento na oferta de alimentos, a elevação do nível de renda, com a consequente melhoria na qualidade de vida dos assentados (INSTITUTO INTERAMERICANO DE COOPERAÇÃO PARA A AGRICULTURA, 2011).

Feitas essas considerações, o objetivo deste artigo é descrever o perfil socioeconômico e calcular o Índice de Sustentabilidade Ambiental (ISA) e o Índice de Participação Política (IPP) dos assentamentos rurais do Distrito Federal (DF) e de seu entorno.

A escolha da área de estudo deve-se ao fato de que, no Distrito Federal, a demanda por alimentos cresce a cada ano, especialmente, no segmento de alimentos orgânicos, que são exatamente os que mais interessam aos assentados produzirem. Isso porque, para eles, a transição agroecológica é responsável por reduzir a 
dependência desses agricultores dos insumos externos, o que representa um grande avanço do ponto de vista da economia de custos. Contudo, a maior parte dos assentamentos - sejam do Movimento dos Trabalhadores Rurais Sem Terra (MST) ou ligados a outras instituições políticas - está no entorno do $\mathrm{DF}$, devido à região distrital ter alta especulação imobiliária e criar entraves à distribuição de terras (RODRIGUES, 2011).

Justificando a importância e a amplitude do estudo, é fundamental pensar a viabilidade dos assentamentos da agricultura familiar não só do ponto de vista da produção de alimentos, mas também de formação de novos agentes sociais capazes de garantir a reprodução econômica, a sustentabilidade e a participação social nas decisões da comunidade.

\section{Metodologia}

A pesquisa concentrou-se na Região Integrada de Desenvolvimento do Distrito Federal e Entorno (Ride DF), onde se encontra grande parte dos assentamentos formados por diversos movimentos sociais, sejam de representação local ou de grandes representações.

O estudo foi realizado por meio de dados primários e secundários, os últimos obtidos em revisão bibliográfica, que foi apoiada em consultas a livros utilizados na formação acadêmica, em monografias, dissertações de mestrado, teses de doutorado, artigos publicados em revistas especializadas que trabalham o tema abordado, sites estatais e órgãos dos setores social e agropecuário. Os dados primários foram obtidos por meio de aplicação de questionários aos assentados de reforma agrária da região. Consta no Apêndice A, deste trabalho, o questionário utilizado na pesquisa de campo.

$\mathrm{Na}$ análise quantitativa da sustentabilidade e da participação política dos assentados, bem como de seus determinantes, foram utilizados dois índices estatísticos. Para mensurar o Índice de Sustentabilidade Ambiental (ISA) dos indivíduos pesquisados, foram elaboradas perguntas que tentaram captar a forma de manejo, conservação e preservação de recursos naturais e do meio ambiente. Assim, a pesquisa baseou-se em parte da metodologia de Damasceno, Khan e Lima (2011), que elabora um Índice de Sustentabilidade com base nos indicadores: Índice de Desenvolvimento Econômico-Social, Índice de Capital Social, Índice Ambiental e Índice Político-Institucional.

Jales et al. (2008) ressaltam que, embora não recebam a devida atenção em determinados setores, os aspectos ambientais são determinantes para a proteção 
das águas, dos solos e da vegetação nativa, sem mencionar a produtividade da atividade e a qualidade dos produtos colhidos.

Pode-se definir, matematicamente, o ISA como:

$$
\mathrm{ISA}=\sum_{i=1}^{n} C_{k}
$$

A forma pela qual cada indicador contribui no ISA dos assentados será obtida da seguinte forma:

$$
C_{k}=\sum \frac{E_{i j}}{E_{i j M a x}}
$$

Em que:

ISA = Índice de Sustentabilidade Ambiental;

$C k=$ contribuição do indicador " $k$ " no Índice de Sustentabilidade Ambiental dos assentados;

$E_{i j}=$ escore da $i$-ésima variável do indicador " $k$ " obtido pelo $j$-ésimo assentado;

Emax $i=$ escore máximo da $i$-ésima variável do indicador " $k$ ";

$i=1, \ldots, n$ (variáveis que compõem o indicador " $\mathrm{k}$ ");

$j=1, \ldots, m$ assentados);

$k=$ indicador que constitui o ISA.

Para mensurar o Índice de Sustentabilidade Ambiental, foram tomados os seguintes indicadores, com variáveis e seus respectivos pesos:

\section{Como é feita a conservação do solo?}

i. Não é realizada nenhuma prática de conservação $\quad 0 / 2$

ii. Por meio de práticas mecânicas $\quad 1 / 2$

iii. Por meio de práticas biológicas $\quad 2 / 2$

2. Que métodos de controle de pragas e doenças o senhor utiliza na unidade produtiva?
i. Agrotóxico
$0 / 2$
ii. Biológico
$1 / 2$
iii. Nenhum método
$2 / 2$

3. Faz utilização de fogo nas atividades agropecuárias?
i. Sim
ii. Não

4. Qual a intensidade (manejo) do uso de veneno?
i. Usa vários produtos
$0 / 2$
ii. Único produto
$1 / 2$
iii. Não utiliza
$2 / 2$ 
5. Qual é o destino dos restos das culturas?

i. Queima

ii. Alimenta animal e / ou vende a terceiros

iii. Incorporação ao solo após a colheita

6. Faz rotação de cultura?

i. Não

ii. Sim

7. Qual adubação utiliza com maior frequência?
i. Químico
ii. Químico e orgânico
iii. Orgânico

8. Como são cultivados os produtos agrícolas?

i. Com máquinas $\quad 0 / 2$

ii. Manualmente e com máquinas $\quad 1 / 2$

iii. Manualmente apenas $2 / 2$

9. A residência possui algum sistema de esgoto ou tipo de fossa?

i. Não

ii. Sim

10. É feito plantio de árvores no lote objetivando a conservação do solo?

i. Não $\quad 0$

ii. Sim

O Índice de Participação Política caracteriza-se pela participação efetiva dos assentados no planejamento de ações coletivas, tomadas de decisões, accountability ${ }^{1}$ local e acompanhamento das ações políticas de nível nacional.

Pode-se definir, matematicamente, o IPP como:

$$
\mathrm{IPP}=\sum_{i=1}^{n} C_{k}
$$

A forma pela qual cada indicador contribui no IPP dos assentados foi obtida da seguinte forma:

$$
C_{k}=\sum \frac{E_{i j}}{E_{i j M a ́ x}}
$$

Em que:

IPP = Índice de Participação Política;

$C_{k}=$ contribuição do indicador " $k$ " no Índice de Participação Política dos assentados;

$E_{i j}=$ escore da $i$-ésima variável do indicador " $k$ " obtido pelo $j$-ésimo assentado; $\operatorname{Emax}_{i}=$ escore máximo da $i$-ésima variável do indicador " $k$ "; 
$i=1, \ldots, n$ (variáveis que compõem o indicador "l");

$j=1, \ldots, m$ (assentados);

$k=$ (indicadores que compõem o IPP).

Para mensurar o IPP, foram tomados os seguintes indicadores, com variáveis e seus respectivos pesos:

1. O senhor participou da organização desse assentamento?

i. Não

ii. Sim

2. O senhor participou de algum acampamento?

i. Não 0

ii. Sim 1

3. O senhor participa ativamente da vida política no assentamento?

$\begin{array}{ll}\text { i. Nunca } & 0 / 3\end{array}$

ii. Às vezes $1 / 3$

iii. Sim, mas acho que poderia ser mais ativo $\quad 2 / 3$

iv. Sim, intensamente $3 / 3$

4. O senhor participa das decisões referentes ao orçamento do assentamento?

$\begin{array}{lll}\text { i. } & \text { Nunca } & 0 / 3 \\ \text { ii. } & \text { Às vezes } & 1 / 3 \\ \text { iii. } & \text { Sim, mas acho que poderia ser mais ativo } & 2 / 3 \\ \text { iv. } & \text { Sim, intensamente } & 3 / 3\end{array}$

5. Com que frequência o senhor participa das reuniões do assentamento e / ou de outras instituições em que participa?

i. Nunca vou $\quad 0 / 3$

ii. Vou algumas vezes $1 / 3$

iii. Vou sempre que posso $2 / 3$

iv. Nunca perco reuniões $3 / 3$

6. O senhor participa das prestações de contas do assentamento e / ou de outras instituições em que participa?

$\begin{array}{ll}\text { i. Nunca } & 0 / 3\end{array}$

ii. Às vezes $1 / 3$

iii. Sim, mas acho que poderia ser mais ativo $2 / 3$

iv. Sim, intensamente $3 / 3$ 
7. O senhor assume ou já assumiu algum cargo ou atividade para o funcionamento de associação, cooperativa, sindicato ou de algum movimento social?

$\begin{array}{llr}\text { i. Não } & 0 \\ \text { ii. } & \text { Sim } & 1\end{array}$

8. O senhor contribui/paga alguma taxa/cota/mensalidade para o funcionamento de associação, cooperativa, sindicato ou de algum movimento social?

i. Não $\quad 0$

ii. Sim 1

9. O senhor acredita que, de alguma forma, a sua militância política teve influência na sua participação efetiva no assentamento?

i. Não 0

ii. Sim 1

10. O que o senhor acha sobre a vida política do país?

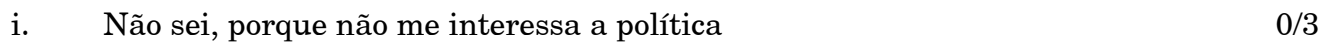

ii. Faço militância política somente em períodos eleitorais $\quad 1 / 3$

iii. Acompanho os fatos da política por entender que sou parte dela $\quad 2 / 3$

iv. Procuro participar intensamente da vida política $\quad 3 / 3$

\section{Marco conceitual}

Nas novas concepções acerca de desenvolvimento, o termo passou a ser interpretado como um processo multidimensional, envolvendo uma verdadeira transformação de sistemas econômicos e sociais. Em suma, verificou-se um processo de mudanças vertiginosas em toda a sociedade mundial, ocasionando uma nova transição de paradigmas econômicos, políticos e sociais. Isso pode ser o resultado de um processo de reordenamento capitalista que, no bojo das transformações impostas pela nova ordem mundial, obriga os atores sociais (governo, mercado e sociedade civil) a repensar o conceito de desenvolvimento, a função pública, a relação entre o setor público e o setor privado e, consequentemente, a relação entre Estado e sociedade (CARDOSO, 2003).

De acordo com Gohn (1995), observa-se, no cenário brasileiro dos anos 1990, a construção de uma nova concepção de sociedade civil. Resultado das lutas sociais empreendidas por movimentos e organizações sociais nas décadas anteriores, reivindicando direitos e espaços de participação social, essa nova concepção constrói uma visão ampliada da relação Estado-sociedade. Isso resultou na criação de uma nova esfera entre o público e o privado, que é o público não estatal, e no 
surgimento de uma ponte de articulação entre essas duas esferas, dada pelas políticas de parcerias.

Ao longo do tempo, o conceito de sociedade civil sofreu muitas reformulações, mas foi ao final dos anos 1970 que o termo ganhou maior destaque, com a convicção de que a sociedade civil deveria se mobilizar e se organizar a fim de alterar o regime militar então vigente, baseado em um ideal focado na noção de autonomia. Destacaram-se os movimentos sociais populares urbanos reivindicatórios de bens e serviços públicos, de terra e moradia, sendo que todos se identificavam pela reivindicação de mais liberdade e justiça social.

No primeiro grande ascenso mobilizatório de emergência do povo brasileiro, que teve início nos anos de 1950, o ponto central era a defesa da soberania por meio de movimentos anti-imperialistas. Foi nesse ciclo que ocorreu a formação das primeiras lutas nacionais no campo brasileiro pela reforma agrária, com a formação das Ligas Camponesas e da União dos Lavradores e Trabalhadores Agrícolas do Brasil, uma organização sindical rural condenada pelo Partido Comunista Brasileiro. Esse ciclo foi interrompido em 1964, de forma abrupta, até os anos de 1970, quando as ideias de democracia ativa e cidadania vão além da questão da soberania. Então, acontece a formação do Movimento dos Trabalhadores Rurais Sem Terra, que herdou as experiências das Ligas Camponesas, com mediação da Comissão Pastoral da Terra. Além disso, surgem as centrais sindicais, a Central Única dos Trabalhadores foi a mais forte entre elas (GUIMARÃES, 2009).

Grzybowski (1987) descreve os movimentos sociais do campo e suas origens pelos seus motivos de lutas. O primeiro citado é o movimento dos posseiros, em que os conflitos pela posse da terra são classificados em três situações: as relações do tipo latifúndio-minifúndio, que predominaram no nordeste do Brasil e findaram com a expulsão dos posseiros por meio de ações de grilagem de terras e pecuarização. O segundo compreende os movimentos dos posseiros na fronteira agrícola, que englobou a Amazônia, o Centro-Oeste, o oeste da Bahia e o norte de Minas. Nessas áreas, a expropriação foi feita por empresas agropecuárias e agroflorestais beneficiadas com incentivos fiscais. Por fim, o terceiro movimento foi desencadeado nos seringais do Acre, onde os posseiros se opuseram à destruição dos seringais pelas novas empresas agropecuárias.

Em seguida, surge o Movimento dos Trabalhadores Rurais Sem Terra, que apresenta um maior grau de articulação interna entre os movimentos de luta pela terra e, por isso, revela maior homogeneidade nas formas de luta em seus vários conflitos particulares. O MST tem grande elo com a Igreja Católica, porém, passa por tensas relações com a estrutura sindical e com as federações. Já o Movimento 
dos Atingidos por Barragens revela novas lutas pela terra. Nesses movimentos, a expropriação é conduzida por grandes projetos de irrigação e ou construção de barragens para geração de energia elétrica.

As outras lutas dos movimentos sociais do campo são contra as formas de exploração e assalariamento, que são movidas pelos trabalhadores operários do campo que exigem o reconhecimento como sujeitos coletivos e se opõem às práticas institucionais que coloquem os direitos sociais em segundo plano. Além dessas, há as lutas contra a subordinação do trabalho ao capital, em que o Movimento dos Camponeses Integrados, formado por uma fração do campo que se modernizou, requer melhores condições de produção e comercialização de seus produtos, haja vista a importância da captação de recursos para o desenvolvimento da agricultura.

Mais recentemente, surgiu o que se denominou de novas frentes de luta, com o objetivo de gerar formas alternativas de desenvolvimento por meio de setores específicos, como os movimentos de mulheres, de cooperativas, de organizações não governamentais, etc.

Grzybowski conclui que:

O campo está prenhe de contradições e se agita de muitas formas. Cruzam e se entrecruzam lutas. Emergem sujeitos sociais de muitas caras, impondo a sua conflituosa presença, exigindo o reconhecimento de seus direitos. A diversidade, reafirmada pelos movimentos sociais no campo, que morrem e renascem, não autoriza pensar que a ampliação da participação econômica, política e cultural dos trabalhadores rurais possa se enquadrar num modelo previamente definido, num caminho exclusivo de democratização (1987, p. 49).

Assim sendo, surge o que podemos chamar de segundo grande momento das mobilizações sociais, que se inicia nos anos 1970 e se prolonga até os dias de hoje. Avritzer (2000) aponta que até os anos 1980 a participação política no Brasil era concentrada basicamente em formas verticais de organização, como a luta pelo poder da terra. Entretanto, é a partir dessa época que surge o que ele chama de "formas híbridas de participação", em que os conselhos, formados tanto pela sociedade quanto pelo Estado, ganham espaços dentro das políticas de saúde, assistência social, meio ambiente, etc.

Gohn (2007) conceitua os movimentos sociais como: "ações coletivas de caráter sócio-político [sic] e cultural que viabilizam distintas formas da população se organizar e expressar suas demandas" (2007, p. 13). Segundo a autora, eles passam a serem vistos por duas concepções: os conservadores, construídos com base em ideologias não democráticas, que podem levar ao terrorismo e negam a ordem social vigente, e os progressistas, que possuem agenda emancipatória, diagnóstico da realidade social, constroem propostas, atuam em redes, articulam ações coletivas 
que lutam pela inclusão social, desenvolvem o empowerment ${ }^{2}$ de atores da sociedade civil organizada. Eis que surge um novo entendimento sobre autonomia, que se relaciona a ter projetos para os grupos com autodeterminação, ter crítica, ser flexível, universalizar demandas particulares e priorizar a cidadania.

Assim, a participação passa a ter um caráter mais amplo:

A Participação Cidadã funda-se também numa concepção democrática radical que objetiva fortalecer a sociedade civil no sentido de construir ou apontar caminhos para uma nova realidade social - sem desigualdades, exclusões de qualquer natureza. Busca-se a igualdade, mas reconhece-se a diversidade cultural. Há um novo projeto emancipatório e civilizatório por detrás dessa concepção que tem como horizonte a construção de uma sociedade democrática e sem injustiças sociais (GOHN, 2007, p. 18).

A autora pergunta: "[...] e os movimentos populares propriamente ditos, aqueles que nos anos 70/80 foram tão importantes, estimulados pela Teologia da Libertação? O que houve com eles? Mudaram de perfil? Desapareceram?” (2007, p. 23). Eles se unificaram pelas carências socioeconômicas e se diversificaram devido às suas temáticas e demandas. Os movimentos populares criaram, ampliaram e fortaleceram a construção de redes sociais. Eles perderam visibilidade, pois saíram do campo reivindicatório para o operativo. Dividiram-se, principalmente, em movimentos populares pela moradia, de saúde, pelos transportes, pelas creches, pela educação, de ambientalistas, etc.

Quanto ao termo sustentabilidade, que é discutido nas plataformas atuais, surge no ano de 1972, quando, a pedido do Clube de Roma, Dennis Meadows e seus colaboradores do Massachussetts Institute of Technology calcularam, pela primeira vez, os limites do crescimento mundial e advertiram acerca do crescimento do consumo dos recursos naturais acompanhados do aumento populacional (KUSTER, 2003).

Além disso, cabe ressaltar outras questões conflitantes ao uso desenfreado de recursos, que estão intimamente ligadas à sustentabilidade e que foram citadas pelo clube: o controle do crescimento da industrialização e a insuficiente produção de alimentos.

Todos esses estudos serviriam de base para o encontro realizado na Noruega, em 1987, quando foi elaborado um documento base, que daria início a uma discussão ampla sobre o tema. Esse documento ficou conhecido como Relatório de Brundtland, e nele estava contido, além da definição oficial, um conjunto de métodos e recomendações a ser seguido pelas nações participantes da comissão para enfrentar a crise que o mundo passava. Em linhas gerais, o texto do referido documento versava sobre a impossibilidade de se atingir o desenvolvimento sem uma 
significativa redução das desigualdades sociais e condenava, de maneira enfática, os atuais modelos de crescimento econômico, que não se ocupavam de verificar sua sustentabilidade em longo prazo.

Contudo, a definição desse conceito não mudou significativamente desde sua inclusão entre as questões mais relevantes do planeta pela Organização das Nações Unidas. Sua evolução se deu após incontáveis aplicações específicas que usaram esse conceito como base. Como exemplo, é possível citar o marketing da responsabilidade, com a sustentabilidade ambiental como estratégia pública de várias empresas, as investigações sobre a sustentabilidade de atividades econômicas específicas, os estudos ainda mais específicos, como avaliações do desenvolvimento sustentável do transporte urbano, entre muitas outras aplicações. É possível verificar, pelo relato anterior, que todas essas aplicações aproveitam o caráter generalista do conceito para utilizá-lo nas mais diversas finalidades. Diante disso, extrai-se que os conceitos de desenvolvimento sustentável discutidos na década de 1980 pouco podem ter passado por alterações comparando-os com as abordagens modernas.

Ao relacionarmos o desenvolvimento ao meio rural, o debate torna-se bem mais recente. Com os altos incrementos tecnológicos no setor agrícola, geram-se discussões acerca das inovações e do apropriacionismo na agricultura. Esse processo, assim chamado, possibilitou um maior controle sobre os recursos necessários na produção e, consequentemente, sobre o resultado final esperado. Criou-se, assim, um modelo de alta produção, com uma agricultura revolucionária, em que os eventos da natureza passaram a ser controlados por intervenções humanas e tecnológicas. Observou-se, a partir do início do século XX, a consolidação de um novo modelo de produção agrícola, com a intensificação no uso de inovações tecnológicas, em busca de melhor performance técnica e econômica, o que acarretou uma severa reformulação de métodos e processos. A agricultura moderna deixou de lado preocupações como reciclagem de nutrientes, conservação do solo e controle de pragas e doenças, para dar total atenção a uma constante intervenção tecnológica e humana nos meios de produção, na qual a tecnologia torna-se elemento fundamental nesse novo organismo de produção em materialização (MELLO, 2005).

Considerando a agricultura como atividade de produção capitalista, Goodman, Sorj e Wilkinson (1990) relatam que a produção direta não poderia ser apropriada pela empresa capitalista devido à indexação a processos naturais, todavia, outros processos poderiam, como no caso do fornecimento de máquinas, adubos, fertilizantes, agrotóxicos e produção de sementes. Os autores baseiam-se nos princípios de apropriacionismo e substitucionismo. O primeiro refere-se à apropriação industrial do processo de produção agrícola, superando as restrições ambientais, 
ou seja, visa a uma substituição de técnicas e processos naturais por técnicas industriais, enquanto o segundo refere-se à substituição dos produtos agrícolas por produtos industriais, fato que está atrelado ao consumo, e não à produção, pois visa diretamente ao consumo, ou seja, ao produto final. Dessa forma, foi necessário o surgimento de novas práticas alimentares que incluíssem os produtos industrializados e a substituição da matéria-prima animal pela vegetal (GOODMAN; SORJ; WILKINSON, 1990).

Um exemplo citado por Goodman, Sorj e Wilkinson (1990) descreve um caso de apropriacionismo. Nos Estados Unidos, o trabalho realizado por homens foi substituído por máquinas movidas por força animal, o que gerou impactos de melhora em outros setores agrícolas. Além disso, os autores citam também o caso da Europa, em que se desenvolveram técnicas de restauração de nutrientes, geradas pela utilização maciça dos solos. Porém, vale ressaltar que essas inovações biotecnológicas só se expandiram com a criação de núcleos de pesquisa em ciência e tecnologia.

Entretanto, Dosi (1988) relata que as soluções para os problemas técnico-econômicos sempre derivam da ciência natural e, assim, segundo o autor, os padrões de inovação possuem três propriedades comuns importantes: a primeira é a existência de padrões normais de mudança tecnológica, que tendem a seguir trajetórias bem definidas por conjuntos específicos de conhecimento e perícia, nos quais adota-se um modelo produtivista e sem preocupação com as formas naturais.

Desse modo, ocorreu uma ruptura quanto à utilização de práticas naturais, um caminho que proporcionou resultados, como a melhoria na produtividade média da terra, o que, do ponto de vista capitalista, é mais efetivo que a situação anterior, podendo ser destacada como uma atividade da trajetória ao longo do espaço econômico e tecnológico. As inovações aplicadas para o alcance de melhor performance nos mercados podem assumir diversas formas e dimensões. Dentre essas formas, podem-se caracterizar as inovações como radical ou incremental, em função da mudança que ocasionam e do ambiente em que estão inseridas.

A segunda propriedade é quanto às alterações de paradigma, que podem gerar padrões descontínuos de mudança tecnológica, haja vista que o lançamento de um produto totalmente novo gera mudanças radicais e, assim, atrela o processo às incertezas do mercado e aos padrões tecnológicos complexos.

Já a terceira propriedade, da irreversibilidade do avanço tecnológico, destaca a questão da irreversibilidade do progresso tecnológico, ou seja, o retorno a processos e métodos produtivos anteriores. No caso de produtos agrícolas, isso não é possível pelo fato de existirem formas alternativas de manejo, como no caso de alimentos orgânicos. 
Nesse sentido, o ressurgimento de métodos alternativos de produção indica o poder de reversibilidade da produção agrícola e que o processo de inserção de novas tecnologias no campo teve um efeito muito importante para o mundo como um todo, que vivia a constante ameaça de uma produção insuficiente diante das necessidades alimentares. Vale destacar que o processo de modernização da agricultura trouxe contribuições incontestáveis em termos de produtividade, apesar de impactos também negativos para a natureza e a saúde humana.

Contudo, enquanto as biotecnologias apresentam um alto nível de adequação com o perfil formal do pós-fordismo (menos matérias-primas e insumos de energia, maior flexibilidade tanto em termos de processos quanto de produtos), sua adoção, como vimos, tem sido limitada pela incerteza da resposta do consumidor e pela hostilidade disseminada dentro de significantes grupos de agentes (WILKINSON, 1993, p. 345).

Para Wilkinson, “[...] o apelo ao produto agrícola final natural é agora equiparado ao apelo à reversão para o natural, isto é, de baixo insumo externo e práticas agriculturais" (1993, p. 346). O autor destaca a reversibilidade tecnológica ocorrida na produção agrícola e ressalta que, mesmo ocorrendo inovações tecnológicas que gerem custos menores e uma maior eficiência produtiva, o retorno a modos anteriores pode existir pelo fato de a variável qualidade ser internalizada na agricultura, e assim os produtos serão adaptados às características do consumo.

No entanto, Goes (2009) relata um problema socioambiental inserido no contexto das inovações. Segundo ele, as plataformas governamentais defendem a inserção das inovações tecnológicas no processo produtivo como forma de solução para os problemas sociais. Sendo que o principal problema de um país, como o caso do Brasil, é a fome e a insegurança alimentar. Nesse caso, o país que apresente esses dois fatores não pode ser considerado desenvolvido. Além disso, as técnicas de produção incentivadas pelas grandes corporações e aceitas pelos governos tendem a agravar mais ainda o caos ambiental do planeta.

Com relação à forma como o progresso técnico na agricultura poderia melhorar o padrão de vida do trabalhador rural, Prado Jr. (1979) é bem pessimista, pois, para ele, a rentabilidade da grande exploração rural não tem relação necessária com a melhoria das condições de trabalho. O que determina e fixa a remuneração do trabalho nas condições atuais da economia rural brasileira é o equilíbrio do mercado de mão de obra, a relação da oferta e demanda que nele se verifica. Para exemplificar que o desenvolvimento agrícola e as condições da vida do trabalhador rural não estão relacionados, o autor exemplifica o caso da lavoura canavieira do nordeste, cujo desenvolvimento e progresso tecnológico foi grande, enquanto que o padrão de vida da população trabalhadora rural piorou. 
Sachs afirma que: "Não basta dizer que o desenvolvimento rural é necessário. Ainda é preciso mostrar que ele é possível" (2010, p. 28). O autor critica a centralização do conceito de modernidade apenas em avanços tecnológicos de biotecnologia, química nuclear, etc. Ele relata que a exploração do trinômio biodiversidade-biomassa-biotecnologia promete futuros radiosos, pois as biotecnologias intervêm nas duas extremidades do processo de produção, tanto para aumentar os rendimentos de biomassa como para alargar o leque dos produtos derivados, como alimentos para homens e animais, adubos verdes, bioenergias, materiais de construção, matérias-primas industriais, insumos para a química verde, farmacopeia, cosméticos. Porém, isso não é o bastante. "Não se trata de jeito nenhum de fazer da civilização vegetal uma panaceia, nem um tema exclusivo de pesquisa, e tampouco negar as funções civilizatórias das cidades ou iniciar um refluxo das populações urbanas para os campos" (SACHS, 2010, p. 29).

Kageyama (2008) afirma que o desenvolvimento rural é visto como um processo que envolve múltiplas dimensões: econômica, sociocultural, político-institucional e ambiental. A análise do desenvolvimento rural deve contemplar o desenvolvimento agrícola e o desenvolvimento da rede urbana local e regional, pois é nesse espaço que muitos membros das famílias agrícolas encontrarão fontes de renda complementares, vitais para a preservação da própria atividade agrícola.

No Brasil, o debate sobre o desenvolvimento rural ganhou força a partir da década de 1990, em função do interesse do Estado e das políticas públicas. Schneider (2010) faz uma boa síntese das principais vertentes de discussão do tema. Segundo o autor, vários fatores contribuíram para reorientar os estudos sobre desenvolvimento rural desde a década de 1990. O primeiro foi o fortalecimento das discussões em torno da agricultura familiar e, principalmente, o seu crescimento como categoria política, ligada à recomposição do movimento sindical dos trabalhadores rurais; o segundo fator importante na emergência do debate sobre desenvolvimento rural resultou da crescente influência do Estado no meio rural com as políticas para a agricultura familiar (Pronaf), a reforma agrária, a segurança alimentar, entre outros efeitos. O terceiro fator diz respeito à mudança de posição das elites agrárias em relação às políticas sociais e compensatórias para o meio rural, a entrada em cena do tema da sustentabilidade ambiental foi o último fator a contribuir para o debate sobre o desenvolvimento rural no Brasil.

Nesse contexto, destaca-se a importância da agricultura familiar e sua participação em ambas as dimensões desse processo. De acordo com os dados do Censo Agropecuário de 2006, realizado pelo Instituto Brasileiro de Geografia e Estatística (IBGE) e Ministério do Desenvolvimento Agrário, três quartos da mão de obra 
ocupada no campo estão ligados aos estabelecimentos familiares, o que representa pouco mais de 12 milhões de pessoas, ao passo que os não familiares são apenas 4,2 milhões de pessoas. Não obstante ocupar apenas $24 \%$ da área, os estabelecimentos familiares respondem por $38 \%$ do valor bruto da produção e por $34 \%$ das receitas no campo. Esse melhor aproveitamento da área pela agricultura familiar fica evidente quando se vê que, enquanto a agricultura familiar gera $R \$ 677 / \mathrm{ha}$, a não familiar gera apenas R\$ 358/ha. Também na ocupação da mão de obra, a agricultura familiar é mais intensiva: ocupa mais de quinze pessoas por 100 ha, enquanto que a não familiar ocupa menos de duas pessoas por 100 ha (DEL GROSSI; MARQUES, 2010). A expressiva ocupação de mão de obra pelos estabelecimentos familiares evidencia a importância desses estabelecimentos na geração de ocupações e desenvolvimento no campo.

Em suma, a agricultura continua a ser a principal atividade do meio rural e, por conseguinte, não pode ser desprezada na análise do desenvolvimento rural. A modernização agrícola, com o seu elevado grau de mercantilização, especialização, escala e padronização das atividades produtivas, tem uma trajetória dominante desde os anos 1970, mas, ainda assim, houve tempo para a manutenção e o crescimento de formas familiares de produção em diversos espaços rurais, como na Região Sul, onde é mais evidente o surgimento de uma nova ruralidade no Brasil.

\section{Resultados e discussões}

Os assentamentos pesquisados neste estudo foram escolhidos de forma aleatória. Tentou-se atender a um critério de tempo e espaço para que não houvesse fortes discrepâncias entre os objetos de estudo. Utilizou-se, neste trabalho, o critério estabelecido pelo Instituto Nacional de Colonização e Reforma Agrária (Incra), que divide o processo de estabelecimento de assentamentos em sete fases ${ }^{3}$ (Tabela 1). 
Tabela 1 - Assentamentos visitados durante a pesquisa

\begin{tabular}{l|c|c|c|c}
\hline \multicolumn{1}{c|}{ Assentamento } & Município & Amostra & Fase & Movimento de base \\
\hline Vanderli Ribeiro & Buritis & 36 & 5 & MST \\
Cunha & C. Ocidental & 22 & 5 & MST \\
Santa Helena & Pe. Bernardo & 43 & 3 & MST \\
Antônio Juvêncio & Pe. Bernardo & 44 & 3 & MST \\
Santa Felicidade & Cocalzinho & 93 & 4 & MST \\
Fazenda Larga & Planaltina & 51 & 4 & MST \\
Oziel Alves III & Planaltina & 40 & 4 & MST \\
Gabriela & Brazlândia & 21 & 4 & MST \\
Graziela & Brazlândia & 6 & 4 & MST \\
Betinho & Brazlândia & 22 & 5 & Movimento local \\
Três Conquistas & Paranoá & 30 & 4 & MST \\
\hline \multicolumn{2}{c|}{ Total } & & \multicolumn{2}{|c|}{}
\end{tabular}

Fonte: elaboração dos autores com base em dados do Incra (2012), Emater (2013) e Seagri (2013).

No entanto, conforme já citado na pesquisa, a maioria dos assentamentos da Ride DF surgiu durante as décadas de 1990 e 2000, e esse fator também influenciou na escolha como alvo da pesquisa. Foram visitados onze assentamentos no período compreendido entre outubro e dezembro de 2013. Ao total, foram 408 entrevistados, sendo: 202 no estado de Goiás, 36 no estado de Minas Gerais e 170 no Distrito Federal. Conforme dados da Emater-DF e da Seagri-DF, apresentados na Tabela 1, a maior parte desses assentamentos teve como movimento social de base o MST. Todavia, muitos agricultores desses assentamentos, no decorrer do processo de consolidação e amadurecimento, romperam com esse movimento e firmaram filiação com outras instituições e/ou movimentos sociais do campo. Entre eles, estão os sindicatos a Confederação Nacional dos Trabalhadores na Agricultura (Contag), a Federação dos Trabalhadores na Agricultura (Fetraf), a Rede Terra, a Cooperar e a Cáritas.

Dentre os assentamentos relacionados na Tabela 1 , muitos deles ainda contam com o apoio do MST, ao mesmo tempo, os assentados estão filiados a outras organizações. Outros encontram-se divididos tanto em espaço como em ideais, é o caso do Assentamento Santa Felicidade, situado em Cocalzinho de Goiás, que, atualmente, conta com 183 famílias assentadas, sendo que, aproximadamente, 100 delas romperam com o MST e decidiram construir as casas em formato de agrovila, diferente dos demais, que continuaram em lotes individuais, na forma de chácaras. No primeiro caso, o ambiente residencial ficou separado da unidade produtiva que é de caráter coletivo. A maioria dos que decidiram pela unidade coletiva, 
atualmente, conta com uma cooperativa e são filiados a entidades ligadas à Fetraf e/ou à Contag.

Em assentamentos como Antônio Juvêncio, Vanderli Ribeiro, Fazenda Larga e Betinho, alguns assentados relataram que, por não estarem filiados a entidades associativas locais ou comunitárias, muitas vezes, eles são impedidos do acesso a auxílio e a benefícios que chegam à comunidade por meio de órgãos governamentais ou privados.

Durante a pesquisa, observou-se alguns lotes que não contavam com energia elétrica, nesse caso, no Assentamento Santa Helena, que fica a poucos metros de outro conjunto de lotes com acesso à rede elétrica. Umas das razões para esse fato, relatada por uma das assentadas, foi por ela não ser filiada à associação local no período de instalação e execução do projeto de infraestrutura de energia elétrica. No entanto, mesmo os que são filiados, por diversas vezes, também podem ficar à margem desses recursos, pois, dentre os 408 entrevistados, apenas $25 \%$ deles disseram participar ativamente da prestação de contas da comunidade ou das entidades às quais são filiados.

Outro fator observado foi a questão do acesso aos bens de capital. Em diversos casos, as máquinas e os equipamentos, que são coletivos por conquista comunitária, ficam centralizados em uma entidade que adota meios e procedimentos burocráticos que colocam entraves de acesso às famílias de baixa renda e capital. Além disso, muitas não recebem orientação adequada de uso dos equipamentos.

Sendo assim, notou-se que a interação dos assentados pesquisados com outras instituições e o desligamento de alguns dos movimentos rurais de base podem ter ocasionado uma ruptura entre o fiel sentido da participação política e a sustentabilidade de nível local.

A Tabela 2 apresenta uma visão concisa das variáveis que compõem e determinam o comportamento dos assentados quanto às suas ações e práticas de sustentabilidade ambiental e participação política. 
Tabela 2 - Estatísticas descritivas das variáveis dos modelos

\begin{tabular}{l|c|c|c|c}
\hline \multicolumn{1}{c|}{ Variáveis } & Mínimo & Máximo & Média & Desvio padrão \\
\hline Anos de estudo do chefe de família & 0 & 16 & 5,08 & 4,02 \\
Anos de estudo do cônjuge & 0 & 21 & 5,32 & 3,97 \\
Participação feminina (\% dos assentados) & 0 & 1 & 0,36 & 0,48 \\
Idade & 18 & 80 & 48,60 & 13,00 \\
Tamanho da família & 1 & 23 & 3,85 & 2,21 \\
Experiência de trabalho & 1 & 75 & 38,48 & 14,57 \\
Área (em hectares) & 1 & 50 & 12,53 & 7,07 \\
Renda (em R\$) & 0 & $7.000,00$ & 944,12 & 928,11 \\
Beneficiários do Bolsa Família & 0 & 1 & 0,47 & 0,50 \\
Aposentadoria & 0 & 1 & 0,18 & 0,39 \\
Assistência técnica & 0 & 1 & 0,33 & 0,47 \\
Católico & 0 & 1 & 0,58 & 0,49 \\
Evangélico & 0 & 1 & 0,34 & 0,47 \\
Uso de agrotóxicos & 0 & 1 & 0,59 & 0,49 \\
Residência com fossa séptica & 0 & 1 & 0,91 & 0,28 \\
Prática de reflorestamento & 0 & 1 & 0,89 & 0,31 \\
Participou de acampamento & 0 & 1 & 0,72 & 0,45 \\
Influência da militância & 0 & 1 & 0,74 & 0,44 \\
ISA & 0,30 & 1 & 0,66 & 0,13 \\
IPP & 0 & 1 & 0,62 & 0,24 \\
\hline
\end{tabular}

Fonte: elaborada pelos autores com base em dados de pesquisa de campo.

Durante a pesquisa com os assentados, optou-se por entrevistar preferencialmente o chefe de família, para mensurar, de forma mais efetiva, o caráter de representatividade e empoderamento deles em relação à comunidade. A variável sexo nesta pesquisa é considerada de valor binário, em que o sexo masculino recebeu o valor de 0 e feminino de 1 . Conforme a Tabela 2, observou-se, na amostra, que os indivíduos do sexo masculino predominam, com um total de, aproximadamente, $60 \%$ dos assentados. No entanto, em média, 36\% dos chefes de família são mulheres, número bastante considerável, que ressalta a inserção da mulher no meio rural, haja vista que, segundo dados do IBGE (2010), elas compõem em torno de $45,6 \%$ da população rural da Ride DF. Além disso, estão ligadas a diversas causas e lutas do campo, como é o caso da Marcha das Margaridas ${ }^{4}$, entre outras manifestações. A variável escolaridade foi medida por meio do total de anos de estudo do chefe da família e do cônjuge, em ambos os casos, percebeu-se que, em média, os 
assentados têm o nível fundamental incompleto. Foram observados valores de 0 , em que o indivíduo relatou nunca ter frequentado a escola, bem como 21 anos de estudo, pois encontrou-se um assentado que concluiu doutorado.

Nesse caso, constatam-se diversos fatores que podem influenciar esses resultados, entre eles, pode-se citar o fato de a maioria dos assentamentos só ter escolas que ofertam apenas o ensino fundamental. Para a progressão nos estudos é necessário o deslocamento para outras localidades rurais ou urbanas, o que apresenta diversos entraves e riscos devido à qualidade do transporte e das estradas, à jornada de trabalho e, muitas vezes, à restrição orçamentária, haja vista que o avanço no nível escolar exige maiores gastos.

O cônjuge apresenta média um pouco maior, representando 5,32 anos de estudo contra 5,08 do chefe da família Os dados aproximam-se bastante dos dados dos chefes. Contudo, há uma melhora quanto ao acesso dos primeiros ao ensino superior de graduação e pós-graduação. Isso pode se relacionar com o fato de maior disponibilidade de tempo para dedicação aos estudos bem como pela faixa etária mais acentuada. Outro fator observado nos assentamentos foi o aumento da pluriatividade, que faz com que os assentados busquem oportunidades em outras atividades econômicas, usando os meios de qualificação como um dos principais canais de busca.

A idade média dos chefes de família foi de 48,60 anos, com desvio padrão igual a 13,00, o que revela uma variação média entre 35,60 e 61,60 anos de idade. A amplitude da amostra apresenta valor mínimo de 18 e máximo de 80 anos. Com base nos dados da pesquisa, observa-se a baixa presença de jovens, até 30 anos, que, nesse caso, pode ser causada pela pouca perspectiva de melhora em relação ao futuro bem como por acesso a tecnologias e outras diversas oportunidades que podem estar longe ou até ser indisponíveis no meio rural. Como é o exemplo de assentamentos que foram visitados, que ficam até, aproximadamente, 300 quilômetros de Brasília, capital federal e integrante da Ride, como foi o caso do assentamento Vanderli Ribeiro, em Buritis, MG.

Quanto à experiência de trabalho, optou-se por subtrair a idade atual do assentado pela idade na qual ele declarou ter começado a trabalhar. Essa variável apresentou média de, aproximadamente, 38,5 anos de trabalho, com variação média entre 24 e 53 anos. Mesmo com uma dispersão dos resultados, um pouco elevada em relação à média, os dados revelaram que os assentados começam a trabalhar muito cedo, muitos iniciam a realizar alguma atividade aos 5 anos de idade, em âmbito familiar e em atividades relacionadas à agropecuária.

As famílias pesquisadas apresentam variação média entre dois e seis integrantes, com valor mínimo de 1 e máximo de 23. Em média, o tamanho das famílias é relativamente pequeno, sendo constituídas, aproximadamente, por quatro 
integrantes. Observou-se a presença ainda forte da migração para áreas urbanas, principalmente, dos filhos, o que leva a reflexões sobre o pouco desenvolvimento social e econômico que o campo brasileiro oferece a seus moradores. Contudo, no caso das famílias que possuem grandes lotes, o número de integrantes, muitas vezes, é maior, pois se observou que os filhos casam e constroem sua residência no lote dos pais.

As áreas dos lotes das famílias pesquisadas apresentaram média de 12,5 hectares, com variação média entre 5,5 e 19,5. Áreas menores, especulação imobiliária, subsídios para a indústria de grande escala, grilagem e fazendas para fins de lazer relacionam-se com as menores áreas, principalmente, com as que ficam mais próximas ao DF.

Os assentados declararam renda média familiar de $\mathrm{R} \$ 944,12$, sendo que essa variável oscila em relação à sua média entre $R \$ 16,00$ e $R \$ 1.872,23$. O valor mínimo declarado foi de $\mathrm{R} \$ 0,00$ e máximo de $\mathrm{R} \$ 7.000,00$. Muitos assentados relataram, dentro da família, não haver nenhum tipo de rendimento fixo e que dependiam de outras fontes, como trabalhos eventuais dentro do próprio assentamento. Os valores mais elevados de renda foram declarados, em maior parte, nos assentamentos mais próximos ao DF, devido ao fato de muitos assentados terem acesso à maior oferta de trabalho, principalmente da administração pública. Entretanto, também se observou rendimentos familiares mais elevados nos assentamentos com maior presença de bens de capital, como máquinas e equipamentos, devido ao investimento expressivo na agricultura de alta escala, gerando empregos e, consequentemente, maior renda agregada.

A renda média das famílias ultrapassou o valor de um salário mínimo vigente, considerando-se o valor de $\mathrm{R} \$ 678,00$. Além de remunerações baseadas em trabalho assalariado, a renda advinda por meio do Bolsa Família apresentou uma forte presença na composição dos ganhos familiares, pois $47 \%$ dos assentados entrevistados afirmaram serem beneficiários do programa. As aposentadorias foram observadas em $18 \%$ das famílias, visto que, aproximadamente, $19 \%$ delas têm indivíduos com mais de 60 anos. Isso se relaciona ao fato de a aposentadoria rural ser concedida aos 55 anos de idade para mulheres e aos 60 anos para homens.

A assistência técnica, quando disponível, é de fundamental importância, pois oferece o acompanhamento necessário para que a produção possa conseguir um padrão desejável de qualidade e produtividade, maximizando recursos e visando resultados sustentáveis. Nesse aspecto, a pesquisa de campo revelou que, em média, apenas $33 \%$ dos assentados afirmam receber algum tipo de assistência. Os dados revelam que, no assentamento mineiro, e nos demais goianos, mais de $90 \%$ dos assentados afirmaram que não recebem nenhum tipo de assistência técnica. Enquanto que no DF, 70\% deles afirmaram que recebem. Vale ressaltar que essas 
são áreas, em média, menores, e onde se predomina a agricultura irrigada e em grande escala. No entanto, em 18 de dezembro de 2013, foi sancionada a Lei $\mathrm{n}^{\circ}$ 12.897, que regulamenta, em seu artigo $1^{\text {ㅇ․ }}$

Fica o Poder Executivo federal autorizado a instituir Serviço Social Autônomo com a finalidade de promover a execução de políticas de desenvolvimento da assistência técnica e extensão rural, especialmente as que contribuam para a elevação da produção, da produtividade e da qualidade dos produtos e serviços rurais, para a melhoria das condições de renda, da qualidade de vida e para a promoção social e de desenvolvimento sustentável no meio rural (BRASIL, 2013).

A nova agência terá como principal objetivo qualificar e ampliar os serviços de Assistência Técnica e Extensão Rural no Brasil, auxiliando pequenos agricultores em projetos que contribuam para o aumento da produtividade e a melhoria das atividades rurais ${ }^{5}$. Essa iniciativa pode ser considerada de grande importância, uma vez que, sem esse acompanhamento, resta à produção familiar um produto de baixíssima qualidade e com pouca produtividade, que não se insere no mercado consumidor, depreciando o investimento realizado e, muitas vezes, comprometendo a continuidade da produção.

A inserção da variável religião na pesquisa deve-se ao fato de que os movimentos sociais do campo tiveram apoio expressivo da Igreja no início das lutas populares pelo desenvolvimento rural sustentável. Ainda hoje, o campo conta com o apoio em projetos e parcerias da Cáritas, da Associação Cristã de Base, da Comissão Pastoral da Terra, entre outras organizações. Todas as entidades citadas são ligadas à Igreja Católica, que, segundo dados da Tabela 2 , é professada por $58 \%$ dos assentados entrevistados, em média.

Todavia, segundo dados do IBGE (2010), o número de evangélicos cresceu em torno de $61 \%$ no período de 2000 a 2010 , enquanto que o de católicos teve queda de 1,3\% no mesmo período, apontando para forte diversificação das formas de crenças no Brasil. A informação foi confirmada durante a coleta de dados no campo, quando se observou a presença considerável de instituições evangélicas nos assentamentos visitados, registre-se que $33 \%$ dos entrevistados afirmaram seguir algum tipo de religião evangélica.

Nas últimas linhas da Tabela 2, apresentam-se os resultados dos indicadores ISA e IPP bem como de algumas variáveis que os constituíram. Tais índices objetivam analisar variáveis que, em conjunto, resumem o comportamento dos indivíduos quanto à sua sustentabilidade ambiental e participação política.

Segundo os dados da pesquisa, no ISA, a variável uso de agrotóxicos, verificada pelo indicador de controle de pragas e doenças, mostra que 59\% dos assentados, 
em média, fazem uso de agrotóxicos em suas atividades agrícolas. Isso contribuiu para que o índice em análise obtivesse um valor médio de 0,66 em uma escala de 0 a 1 , no qual obteve uma variação de 0,13 em relação à sua média, com intervalo entre 0,53 e 0,79. Contudo, quando se trata da forma de adubação, em diversos casos, foi detectada a utilização de meios orgânicos, como o uso da cama de frango. ${ }^{6}$ Esses resíduos orgânicos são considerados insumos de baixo custo e de alto retorno econômico para a agropecuária, além do retorno direto da atividade. Durante as conversas com os entrevistados, alguns afirmaram que, por diversas vezes, ainda utilizam agrotóxico e adubos químicos, pela acessibilidade. Aqueles que não os utilizam informaram não ter acesso a alguns métodos também por haver desavenças coletivas e institucionais, que impedem que a oferta desses insumos chegue até eles.

Outra variável que contribui positivamente no resultado do ISA foi o fato de 91\% dos assentados, em média, ter instalada fossa do tipo séptica em seu lote. Nesse caso, tentou-se mensurar o comportamento dos assentados quanto à forma de descarte de resíduos humanos domiciliares. Em um desses casos, um morador assentado do Assentamento Cunha, em Goiás, afirmou utilizar a fossa biodigesto$\mathrm{ra}^{7}$. No entanto, em nenhuma ocasião foi citada a utilização de sistema de esgoto.

Por fim, vale ressaltar a importância do reflorestamento para uma ótima preservação do meio ambiente. Essa variável foi bastante significativa na composição do ISA, sendo que essa prática ambiental teve seu uso confirmado por $94 \%$ dos assentados. Segundo Shintow e Quiroz (2003), Pender et al. (2004 apud DUARTE, 2009), a prática de reflorestamento exerce um efeito positivo na conservação do meio ambiente. $\mathrm{O}$ termo reflorestamento aplica-se apenas à implantação de florestas em áreas naturalmente florestais que, por ação antrópica ou natural, perderam suas características originais. Nos assentamentos pesquisados, neste estudo, muitos deles foram instituídos a partir da desapropriação de indústrias e fazendas, como é o caso do Assentamento Santa Felicidade, em Goiás, no qual, segundo relatos dos assentados, antes do assentamento, existia uma empresa que explorava minério e que deixara a área bastante degradada.

Quanto ao IPP, esse índice obteve um valor médio de 0,62 em uma escala de 0 a 1. Sendo que apresentou um desvio padrão de 0,24 , o que retrata uma variação em relação ao valor médio no intervalo de 0,38 a 0,86 . As principais variáveis que contribuíram de forma expressiva na composição do IPP foram as que trataram da organização inicial do assentamento, a participação em acampamentos que antecederam a comunidade e a militância exercida em movimentos sociais do campo. Em média, $72 \%$ dos assentados afirmaram ter participado de acampamentos rurais 
que antecedem a formação de um assentamento. Em alguns casos, foi relatada participação em diversos acampamentos antes de se tornar assentado definitivo. Ademais, $74 \%$ deles afirmaram que a militância política contribuiu consideravelmente para a decisão de ir viver em um assentamento.

Vale ressaltar que, bem como os movimentos sociais se mostram importantes na busca e defesa das vivências e modos de vida rurais dignos e sustentáveis, a participação nas fases de organização inicial de assentamentos e em acampamentos também são primordiais, pois nelas são tracejados e decididos os rumos da comunidade, são conhecidas as características da terra e suas finalidades, assim como todos os recursos que ela poderá oferecer para os assentados e quais formas poderão ser melhor utilizadas.

\section{Considerações finais}

Ao realizar o levantamento dos assentamentos da Região Integrada de Desenvolvimento do Distrito Federal e Entorno, claramente observaram-se divergências entre os dados apresentados por diversos órgãos governamentais e entidades ligadas ao campo. Isso se refletiu, principalmente, na classificação quanto ao estágio de maturação. A classificação adotada pelo Incra, por exemplo, fragmenta esse processo em sete fases, o que indica diversas discrepâncias quanto à realidade vista na pesquisa de campo. Sendo assim, não se pode considerá-los de forma rígida em pesquisas e estudos que visem analisar condições socioeconômicas e comportamentos de indivíduos assentados.

O perfil socioeconômico dos assentados por reforma agrária da Ride DF apresenta traços de dicotomia impostos ao meio rural, pois o homem do campo ainda é visto como ator marginal na transformação de seu próprio meio. $\mathrm{O}$ nível de escolaridade é baixo, devido aos desníveis na oferta de políticas educacionais voltadas para a realidade rural. Dentre os assentamentos visitados durante a pesquisa, apenas em um deles, no estado de Goiás, Assentamento Santa Helena, foi relatada a presença de indivíduos selecionados em edital do Programa Nacional de Educação na Reforma Agrária, que é voltado para a promoção de potencialidades locais e garantia de práticas sustentáveis e coletivas. Nesse caso, o programa foi executado por meio da oferta de um curso de nível médio técnico, dentro da educação profissional e que foi ofertado pelo Instituto Federal de Brasília. No entanto, só houve uma turma formada e, atualmente, não há nenhuma em andamento. Todavia, foi observado um número razoável de assentados que têm acesso ao ensino superior de graduação e de pós-graduação. 
Quanto aos movimentos sociais do campo, entre os assentamentos visitados, apenas um deles não teve como movimento de base o Movimento dos Trabalhadores Sem Terra, embora muitos deles não tenham mais vínculo efetivo com o MST. Foi identificada a presença de outros movimentos e instituições atuando no meio rural pesquisado, em sua maioria, considerados progressistas, divergindo dos ideais conservadores dos movimentos sociais do campo que se iniciaram nas décadas de 1960 e 1970. Ao mesmo tempo, esse fato mostra um avanço da participação da sociedade civil com a maior presença das instituições de representatividade, sendo, em certa parte, demanda do "novo rural", que se apresenta e exige um novo cenário de participação mais efetiva e melhores práticas ambientais.

Já quanto à assistência técnica, observou-se pouco atendimento desse tipo de serviço entre os assentados. Os assentamentos que recebem esse tipo de assistência são atendidos pelas diversas instituições e entidades que também atuam na representatividade dos indivíduos, demonstrando, também, uma maior diversificação dos movimentos e grupos sociais. No entanto, conforme relatado no corpo deste trabalho, em dezembro de 2013, foi criada uma empresa federal de assistência técnica com vistas a regularizar os desníveis na oferta desse tipo de atendimento ao homem do campo.

As famílias são menos numerosas, o que pode comprometer a manutenção do ambiente rural e suas vivências. Ainda, observou-se alta média de idade, configurando pouca presença de jovens até 30 anos nos assentamentos da região do DF e entorno. Outro fato observado foi a alta média de experiência laboral dos assentados, em torno de 38 anos, determinada pelo fato de a maioria ter começado a exercer atividades no campo, em média, já com 10 anos de idade. A população com mais de 60 anos aproxima-se do total de $20 \%$ da amostra analisada, o que faz com que grande parte da renda dos assentados seja composta pelas aposentadorias e benefícios da Previdência e Assistência Social.

A partir da metodologia proposta, foi exposto que o Índice de Sustentabilidade Ambiental apresentou um valor médio de 0,66 , pois foram detectados o uso de fossas sépticas tradicionais como também de agrotóxicos, e ainda a utilização de fogo nas atividades agropecuárias, em contrapartida, foram observadas boas práticas de adubação e reflorestamento. Já o Índice de Participação Política obteve valor médio menor do que o ISA, em torno de 0,62 considerando-os em uma escala de 0 a 1. Na composição desse último, a participação em acampamento e a militância política obtiveram altos percentuais. Entretanto, os assentados precisam de melhoras em indicadores como participação em prestações de contas locais e ações de transparência, acompanhamento mais frequente da política do país e uma maior descentralização de cargos e funções nas instituições que os representam. 


\title{
Analysis of performance environmental and political in rural settlements of the Federal District and surrounding
}

\begin{abstract}
The purpose of this article was to describe the sociodemographic and perform an analysis of environmental and political behavior of the settlers present in the rural settlements of the Federal District and surrounding areas. Workings of the socioeconomic profile and the measurement of environmental and political behavior of the settlers were derived by calculating the Environmental Sustainability Index and Political Participation Index, in which 408 questionnaires were administered in 11 settlements in the Region integrated Federal District and Surrounding Development. Found the presence of traces of rural dichotomy imposed on, for example, the farmer is still seen as a marginal actor in the transformation of their own half. The level of education is low, even caused by gaps in the provision of educational policies aimed at rural reality. The settlers have intermediate levels in both behaviors, measured by the index, and some indicators analyzed need to be improved, as well as others need to be leveraged.
\end{abstract}

Keywords: Environmental sustainability. Political participation. Settlements.

\section{Análisis de comportamiento ambiental y politico en asentamientos campesinos del Distrito Federal y entorno}

\section{Resumen}

El objetivo de este artículo fue describir el perfil socioeconómico y realizar análisis del comportamiento ambiental y político de los asentados campesinos del Distrito Federal y Entorno. Las construcciones del perfil socioeconómico y la medición del comportamiento político y ambiental de los asentados resultaron de cálculo del Índice de Sustentabilidade Ambiental y del Índice de Participação Política. Fueron utilizados 408 cuestionarios en 11 asentamientos de la Região Integrada de Desenvolvimento do Distrito Federal e Entorno. Se constató la existencia de aspectos de dicotomía relegados al ambiente campesino, como, por ejemplo, el hombre del campo todavía es visto como actor marginal en el desarrollo de su propio ambiente. El nivel de escolarización es bajo, aún causado por desproporciones en la oferta de políticas educacionales pensadas para la realidad campesina. Los asentados están en el nivel intermedio en ambos comportamientos, medidos por los índices, sabiendo que algunos indicadores analizados necesitan ajustes, a la vez que otros necesitan ser potenciados.

Palabras clave: Asentamientos. Participación política. Sustentabilidad ambiental. 


\section{Notas}

1 Esse termo pode ser considerado, em geral, polissêmico. Neste trabalho, ele terá um significado de prestação de contas, transparência e controle de ações coletivas.

2 De acordo com o Dicionário Oxford, empowerment significa autoridade ou poder para fazer algo. No caso de um fenômeno sociológico, refere-se a um aumento de força política e social de um grupo ou movimento (OXFORD UNIVERSITY PRESS, ( ) 2016).

3 Compreende-se: 00 - em obtenção; 01 - pré-projeto de assentamento; 02 - agricultores do assentamento em criação; 03 - assentamento criado; 04 - assentamento em instalação; 05 - assentamento em estruturação; 06 - assentamento em consolidação; 07 - assentamento consolidado.

4 A Marcha das Margaridas é uma ação estratégica das mulheres do campo e da floresta que integra a agenda permanente do Movimento Sindical de Trabalhadores e Trabalhadoras Rurais e de movimentos feministas e de mulheres. Tem como objetivo proporcionar a reflexão sobre as condições de vida das mulheres do campo e da floresta. Por ser permanente, as mulheres trabalhadoras rurais lutam, diariamente, para romper com todas as formas de discriminação e violência, que trazem consequências danosas. É coordenada pela Confederação Nacional dos Trabalhadores na Agricultura, pelas 27 Federações de Trabalhadores na Agricultura, pelos mais de 4 mil Sindicatos dos Trabalhadores e Trabalhadoras Rurais, e por várias organizações de mulheres parceiras. Disponível em: <http://www.contag.org.br/index.php?modulo=portal $\& a c a 0=$ interna\&codpag=256\&nw=1>. Acesso em: 18 dez. 2013.

5 Disponível em: <http://www.brasil.gov.br/economia-e-emprego/2013/12/embrapa-participa-da-formatacao-da-anater>. Acesso em: $28 \mathrm{dez} .2013$.

6 A cama de frango é uma excelente fonte de nutrientes, especialmente nitrogêneo, e quando manejada adequadamente, pode suprir, parcial ou totalmente, o fertilizante químico na produção de grãos. Além do benefício como fonte de nutrientes, o seu uso adiciona matéria orgânica que melhora os atributos físicos do solo, aumenta a capacidade de retenção de água, reduz a erosão, melhora a aeração e cria um ambiente mais adequado para o desenvolvimento da flora microbiana do solo (SILVA; FRASSETO, 2012).

7 O processo de biodigestão de resíduos orgânicos é bastante antigo. A primeira unidade foi instalada em Bombaim, na Índia, em 1819. Na Austrália, uma companhia produz e industrializa metano produzido com o esgoto desde 1911. A China tem 4,5 milhões de biodigestores que produzem gás e adubo orgânico, tendo como principal função o saneamento no meio rural. No Brasil, a ênfase para os biodigestores foi dada para a produção de gás, com o objetivo de converter a energia do biogás em energia elétrica por meio de geradores. Isso permitiu melhorar as condições rurais, com o uso de ordenhadeiras e outros benefícios que podem ser introduzidos. Esse processo realiza-se por meio da decomposição anaeróbica da matéria orgânica digerível por bactérias que a transforma em biogás e efluente estabilizado e sem odores, que pode ser utilizado para fins agrícolas. Com isso, o processo de biodigestão de resíduos orgânicos é uma possibilidade real a ser considerada para a melhoria do saneamento no meio rural (OLSEN; LARSEN, 1987 apud NOVAES et al., 2007).

\section{Referências}

AVRITZER, L. Teoria democrática e deliberação pública. Lua Nova: Revista de Cultura e Política, São Paulo, n. 50, p. 25-46, 2000. Disponível em: <http://www.scielo.br/pdf/ln/n50/a03n50. pdf>. Acesso em: $10 \mathrm{dez} .2012$.

BERGAMASCO, S. M. P. P.; NORDER, L. A. C. O que são assentamentos rurais? São Paulo: Brasiliense, 1996. (Coleção Primeiros Passos, 301).

BRASIL. Lei nº 12.897, de 18 de dezembro de 2013. Autoriza o Poder Executivo federal a instituir serviço social autônomo denominado Agência Nacional de Assistência Técnica e Extensão Rural - ANATER e dá outras providências. Brasília: Presidência da República Federativa do Brasil, 2013. Disponível em: <http://www.planalto.gov.br/ccivil_03/_Ato2011-2014/2013/Lei/L12897. htm>. Acesso em: 4 jan. 2014. 
CARDOSO, G. C. de C. As dinâmicas institucionais e os novos paradigmas de desenvolvimento: novos atores, novos papéis, velhas práticas? In: SEMANA DE HUMANIDADES DA UFRN, 11, 2003, Natal. Anais... Natal: UFRN, 2003.

DAMASCENO, N. P.; KHAN, A. S.; LIMA, P. V. P. S. O impacto do Pronaf sobre a sustentabilidade da agricultura familiar, geração de emprego e renda no Estado do Ceará. Revista de Economia e Sociologia Rural, v. 49, n. 1, p. 129-156, 2011. Disponível em: <http://www.scielo.br/pdf/resr/ v49n1/a06v49n1.pdf>. Acesso em: 1 mar. 2013.

DEL GROSSI, M. E.; MARQUES, V. P. M. A. Agricultura familiar no censo agropecuário 2006: o marco legal e as opções para sua identificação. Estudos Sociedade e Agricultura, Rio de Janeiro, v. 18 , n. 1, p. 127-157, 2010.

DEL GROSSI, M. E.; SILVA, J. G. da. Novo rural: uma abordagem ilustrativa. Londrina: IAPAR, 2002. v. 1.

DOSI, G. The nature of the innovative process: technical change and economic theory. London: Printer, 1988. p. 221-238.

DUARTE, G. B. Práticas agrícolas e degradação ambiental: um estudo para o caso da agricultura familiar no nordeste do Brasil. Tese (Doutorado em Economia) - Universidade Federal de Pernambuco, Recife, 2009.

GOES, C. R. A produção de alimentos sob a égide da empresa capitalista: a produção de soja no Rio Grande do Sul. Trabalho de conclusão de curso (Bacharelado em Ciências Sociais) - Universidade Federal do Rio Grande do Sul, Porto Alegre, 2009. Disponível em: <http://www.lume.ufrgs. br/bitstream/handle/10183/18447/000729277.pdf?sequence=1>. Acesso em: 17 jul. 2012.

GOHN, M. da G. Conselhos gestores e participação sociopolítica. São Paulo: Cortez, 2001. (Coleção Questões da Nossa Época, v. 84).

. História dos movimentos e lutas sociais: a construção da cidadania dos brasileiros. 2. ed. São Paulo: Loyola, 1995.

. Movimentos sociais no inicio do século XXI: antigos e novos atores sociais. 3. ed. Petrópolis: Vozes, 2007.

GOODMAN, D.; SORJ, B.; WILKINSON, J. Da lavoura às biotecnologias: agricultura e indústria no sistema internacional. Rio de Janeiro: CEPS, 1990. Disponível em: <www.bvce. org\%2FDownloadArquivo.asp\%3FArquivo\%3DGOODMAN_SORJ_WILKINSON_da_Lavoura_ as_Biotecnologias.pdf\&ei=anoJUIjsBOyN6QGNpO3uCg\&usg=AFQjCNGjS95m7tM2YBVRIebq jCX4xC_rfw>. Acesso em: 15 jul. 2012.

GRZYBOWSKI, C. Caminhos e descaminhos dos movimentos sociais no campo. Petrópolis: Vozes, 1987.

GUIMARÃES, J. R. Culturas brasileiras da participação democrática. In: AVRITZER, L. (Org.). Experiências nacionais de participação social. São Paulo: Cortez, 2009.

INSTITUTO BRASILEIRO DE GEOGRAFIA E ESTATÍSTICA. Censo 2010. Disponível em: <www.ibge.gov.br>. Acesso em: 15 dez. 2013.

INSTITUTO INTERAMERICANO DE COOPERAÇÃO PARA A AGRICULTURA. Produtos Técnicos Abertos: Reforma agrária e assentamentos rurais: perspectivas e desafios. Brasil, 2011. Disponível em: <http://www.iica.int/Esp/regiones/sur/brasil/Lists/DocumentosTecnicosAbertos/ 
Attachments/381/Vanilde\%20Ferreira\%20de\%20Souza\%20Esquerdo\%20-\%20NEAD\%20-\%20 artigo.pdf>. Acesso em: 10 abr. 2013.

JALES, J. V. et al. As políticas públicas e a sustentabilidade dos assentamentos rurais: o caso do estado do Ceará. In: HOLANDA, M. C.; CARVALHO, E. B. S.; BARBOSA, M. P. Economia do Ceará em debate 2007. Fortaleza: IPECE, 2008. Disponível em: <http://www.ipece.ce.gov.br/ publicacoes/Encontro_Economia_Ceara_Debate_2007.pdf>. Acesso em: 7 fev. 2013.

KAGEYAMA, A. A. Desenvolvimento rural: modelos e dinâmicas. Porto alegre: Ufrgs, 2008.

KUSTER, A. Democracia e sustentabilidade: experiências no Ceará, Nordeste do Brasil. Fortaleza: Expressão, 2003. 230 p.

LEFF, E. Saber ambiental: sustentabilidade, racionalidade, complexidade, poder. 6. ed. Petrópolis: Vozes, 2008.

MELLO, J. A. V. Reversão tecnológica no agronegócio: uma estratégia para o setor de alimentos orgânicos. 2005. Disponível em: <www.aedb.br/seget/artigos05/305_artigoorganicos.pdf>. Acesso em: 17 jul. 2012.

NOVAES, A. P. de et al. Utilização de uma fossa séptica biodigestora para melhoria do saneamento rural e desenvolvimento da agricultura orgânica. 2007. Disponível em: <http://www.cnpdia. embrapa.br/produtos/img/fossa.pdf>. Acesso em: 18 dez. 2013.

OXFORD UNIVERSITY PRESS. Oxford Dictionaries Online. (c) 2016. Disponível em: <http:// oxforddictionaries.com/>. Acesso em: 12 abr. 2013.

PRADO JR., C. A questão agrária no Brasil. São Paulo: Brasiliense, 1979.

RODRIGUES, A. C. Avaliação das condições de vida e de produção nos acampamentos e assentamentos rurais do Distrito Federal. 2011. 57 f. Monografia (Graduação em Agronomia) - Faculdade de Agronomia e Medicina Veterinária, Universidade de Brasília, Brasília, 2011. Disponível em: <http://bdm.bce.unb.br/bitstream/10483/1932/6/2011_AnaCarolinaRodrigues.pdf>. Acesso em: 20 out. 2012.

SACHS, I. Barricadas de ontem, campos de futuro. Estudos Avançados, São Paulo, v. 24, n. 68, p. 25-38, 2010. Disponível em: <http://www.scielo.br/pdf/ea/v24n68/05.pdf>. Acesso em: 8 abr. 2013.

SAUER, S.; SOUZA, M. R. Movimentos sociais na luta pela terra: conflitos no campo e disputas políticas. In: FERRANTE, Vera L. B.; WHITAKER, Dulce C. Reforma agrária e desenvolvimento: desafios e rumos da política de assentamentos rurais. Brasília: MDA/NEAD, 2008. p. 53-87.

SCHNEIDER, Sergio. Situando o desenvolvimento rural no Brasil: o contexto e as questões em debate. Revista de Economia Política, São Paulo, v. 30, n. 3, p. 511-531, 2010. Disponível em: <http://www.scielo.br/pdf/rep/v30n3/a09v30n3.pdf>. Acesso em: 7 mar. 2013.

SILVA, M. M. O.; FRASSETO, E. G. Uso da cama de frango no crescimento de mudas nativas do Cerrado. 2012. Disponível em: <http://www.unirv.edu.br/conteudos/fckfiles/files/USO\%20DA\%20

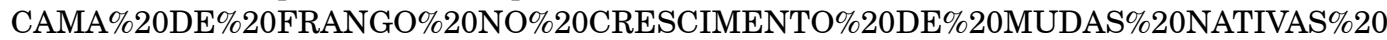
DO\%20CERRADO.pdf>. Acesso em: 15 dez. 2013.

WILKINSON, J. Ajustamento a um sistema de alimentos orientado para a demanda: novos rumos para a inovação biotecnológica. Ensaios FEE, Porto Alegre, v. 14, n. 1, p. 332-348, 1993. Disponível em: <http://revistas.fee.tche.br/index.php/ensaios/article/viewFile/1611/1979>. Acesso em: 15 jul. 2012.

Teoria e Evidência Econômica - Ano 22, n. 46, p. 73-104, jan./jun. 2016 


\section{Apêndice}

\section{Apêndice A - Questionário da pesquisa}

\section{Questionário}

\section{Pesquisa: determinantes de participação política e sustentabilidade em assentamentos rurais do DF e entorno}

№ do questionário

\section{Informações ao entrevistador:}

Caro entrevistador, antes de iniciar a aplicação do questionário, pedimos que se dirija ao entrevistado se apresentando a ele, informando o objetivo de sua entrevista e perguntando se ele concordaria em participar deste trabalho respondendo as $\mathrm{X}$ questões que serão formuladas. Informe a ele que o tempo médio de aplicação do questionário é de $\mathrm{X}$ minutos e que o questionário não identificará pessoas, além do mais, todas as informações coletadas ficarão restritas à análise da pesquisa em curso, com a garantia de total anonimato dos respondentes. Ao encerrar a entrevista, agradeça pela colaboração.

\section{Parte I: informações socioeconômicas}

01. Sexo: ( ) Masculino ( ) Feminino 02. Idade: anos.

03. Como o(a) senhor(a) se identifica em sua relação familiar:

( ) chefe da família ( ) cônjuge ( ) filho ( ) outros

04. Escolaridade: anos

05. Qual o nível de escolaridade do chefe da família? anos

06. Qual o nível de escolaridade do cônjuge da família? anos

1 a 9 - nove primeiros anos ensino fundamental; 10 a 12 - primeiro ao último ano ensino médio; 13 a 16 - ensino superior; 17 e 18 - mestrado; 19 a 22 - doutorado.

07. Tamanho da família (residente no domicílio) incluindo o entrevistado:

08. Origem da família?

( ) Vizinhança ( ) Sede do município ( ) Outros estados ou regiões do Brasil.

09. O(A) senhor(a) começou a trabalhar com quantos anos de idade?

10. Há quanto tempo o senhor está nesse lote?

11. Qual motivo levou o(a) senhor(a) a ingressar no assentamento?
( ) Incentivo da família (
) Incentivo de vizinhos e amigos
( ) Acesso à terra
( ) Acesso a crédito ( ) Outros:

12. $\mathrm{O}(\mathrm{A})$ senhor(a) participa de algum movimento social e ou empreendimento social? Qual?

( ) Não participa ( ) Associação ( ) Cooperativa ( ) MST ( ) Contag ( ) Fetraf

( ) Sindicato de Trabalhadores Rurais ( ) Outro: 
13. O(A) senhor(a )segue ou professa alguma religião? ( ) Não ( Sim

Em caso afirmativo, qual?

( ) Católica Romana ( ) Assembleia de Deus Outros grupos evangélicos:

( ) Outros grupos religiosos:

14. Qual a área de seu lote? ha.

15. Qual a sua principal atividade? ( ) Criação de pequenos animais ( ) Criação de bovinos

( ) Agricultura de sequeiro ( ) Agricultura irrigada ( ) Outro (especifique)

16. Recebe algum tipo de assistência técnica? ( ) Não ( ) Sim

\section{Parte II: índice ambiental}

1. Como é feita a conservação do solo?

( ) Não é realizada nenhuma prática ( ) Através de práticas biológicas ( ) Através de práticas mecânicas

2. Que métodos de controle de pragas e doenças o(a) senhor(a) utiliza na unidade produtiva? ( ) Agrotóxico ( ) Biológico ( ) Nenhum método

3. Faz utilização de fogo nas atividades agropecuárias? ( ) Sim （ ) Não

4. Qual a intensidade (manejo) do uso de veneno?

( ) Usa vários produtos ( ) Único produto ( ) Não utiliza.

5. Qual é o destino dos restos das culturas?

( ) Queima ( ) Alimenta animal ( ) Vende a terceiros ( ) Incorporação ao solo após a colheita.

6. Faz rotação de cultura? ( ) Não ( ) Sim

7. Qual adubação utiliza com maior frequência?

( ) Químico ( ) Orgânico ( ) Os dois

8. Como são cultivados os produtos agrícolas?

( ) Com máquinas ( ) Manualmente e com máquinas agrícolas ( ) Apenas manualmente

9. A residência possui algum sistema de esgoto ou tipo de fossa? ( ) Não ( ) Sim

10. É feito plantio de árvores objetivando a conservação do solo? ( ) Não （ ) Sim

\section{Parte III: participação política}

1. O(A) senhor(a) participou da organização deste assentamento? ( ) Não （ ) Sim

2. O(A) senhor(a) participou de algum acampamento? ( ) Não ( ) Sim

3. $\mathrm{O}(\mathrm{A})$ senhor(a) participa ativamente da vida política no assentamento?

( ) Nunca ( ) Às vezes ( ) Sim, mas acho que poderia ser mais ativo(a) ( ) Sim, intensamente

4. O(A) senhor(a) participa das decisões referentes ao orçamento do assentamento?

( ) Nunca ( ) Às vezes ( ) Sim, mas acho que poderia ser mais ativo(a) ( ) Sim, intensamente

5. Com que frequência o(a) senhor(a) participa das reuniões do assentamento e / ou de outras instituições em que participa?

( ) Nunca vou ( ) Vou algumas vezes ( ) Vou sempre que posso ( ) Nunca perco reuniões

6. $\mathrm{O}(\mathrm{A})$ senhor(a) participa das prestações de contas do assentamento e / ou de outras instituições em que participa?

( ) Nunca ( ) Às vezes ( ) Sim, mas acho que poderia ser mais ativo(a) ( ) Sim, intensamente 
7. $\mathrm{O}(\mathrm{A})$ senhora ocupa ou ocupou algum cargo ou atividade para o funcionamento de associação/cooperativa/ sindicato ou de algum movimento social? ( ) Não （ ） Sim

8. $\mathrm{O}$ (A) senhor(a) contribui/paga alguma taxa/cota/mensalidade para o funcionamento de associação/ cooperativa/sindicato ou de algum movimento social? ( ) Não （ ) Sim

9. $\mathrm{O}(\mathrm{A})$ senhor(a) acredita que de alguma forma a sua militância política teve influência na sua participação efetiva no assentamento? ( ) Não （ ） Sim

10. O que o(a) senhor(a) acha sobre a vida política do país?

( ) Não sei, porque não me interessa a política

( ) Acompanho os fatos da política por entender que sou parte dela

( ) Faço militância política somente em períodos eleitorais

( ) Procuro participar intensamente da vida política

\section{Parte IV: renda familiar}

1. Quais os auxílios recebidos pela família:
A) Cesta básica: ( ) $\operatorname{sim}($ ) não
C) Pensão: ( ) sim ( ) não
B) Benefícios do Programa do Leite: ( ) sim ( ) não
D) Aposentadoria: ( ) $\operatorname{sim}($ ) não
E) Seguro-desemprego: ( ) sim ( ) não
F) Garantia à safra: ( ) sim ( ) não
G) Bolsa família/verde: ( ) $\operatorname{sim}($ ) não

2. Qual sua renda familiar mensal, incluindo o bolsa família e outros programas? $\mathrm{R} \$$ 